\title{
The Impact of Organizational Structure and Funding Sources on the Work and Health of Employed Caregivers in Children's Homes in Ghana
}

\author{
Ernest Darkwah $^{1}$ (D) Marguerite Daniel $^{1}$. \\ Maxwell Asumeng ${ }^{2}$
}

Received: 27 February 2018 / Accepted: 15 June 2018 / Published online: 25 July 2018

(C) The Author(s) 2018

\begin{abstract}
The strategies by which work is organized and carried out and the sources from which organizations obtain funding and other resources for their operations may influence employee outcomes including work performance and health. This study explored how organizational structure (dormitory vs family unit) and funding sources (government vs private) influence the work and health of individuals employed as caregivers in children's homes in Ghana. Using qualitative research techniques we collected data from fifty-seven caregivers across three children's homes in Ghana. We found that the structure adopted by children's homes influence caregiver work performance by increasing work stress levels, complicating some caregivers' ability to bond with the children and limiting the amount of time that some caregivers have to spend with their own families. These influences then exposed caregivers to physical, mental and social health risk factors including injuries from slips and falls, mental strain, and loss of social support. We also found that funding source influence the frequency of training caregivers receive, the extent of help caregivers receive with their own healthcare costs as well as the extent to which caregivers utilize international regulations like child rights principles in doing their jobs. Our findings suggest a need for stakeholder reconsideration of work design and strategizing for the homes taking into account caregiver health and well-being.
\end{abstract}

Ernest Darkwah

Ernest.darkwah@student.uib.no; nanadarkwah@gmail.com

Marguerite Daniel

Marguerite.Daniel@uib.no

Maxwell Asumeng

masumeng@ug.edu.gh

1 Department of Health Promotion and Development, Faculty of Psychology, University of Bergen, P.O. Box 7807, 5020 Bergen, Norway

2 Department of Psychology, University of Ghana, P.O. Box LG84, Legon-Accra, Ghana 
Keywords Children's homes · Organizational structure · Funding sources · Caregivers · Children without parental care $\cdot$ Family-style $\cdot$ Dormitory-style $\cdot$ Health $\cdot$ Work stress

\section{Introduction}

Institutions that provide accommodation and alternative care for children without parental care (CWPC) exist widely despite international criticism of such care arrangements (Dozier 2012; Engle et al. 2011; Whetten et al. 2009; Zeanah et al. 2005). In Ghana, such institutions are known commonly as Children's Homes (CHs). CWPC ${ }^{1}$ are "all children not in the overnight care of at least one of their parents" (United Nations General Assembly 2010: 6). They include children who have lost one or both parents through disease, conflict, illness etc., children living in residential care, with extended families, foster families, on the streets, in juvenile detention and those abandoned by or separated from their biological parents for whatever reasons (Darkwah et al. 2016; EveryChild 2009; O'Kane et al. 2006). Statistics indicate that there are around $111 \mathrm{CHs}$ providing alternative care to some 4457 CWPC across Ghana (Better care Network 2014; Bettmann et al. 2015; Department of Social Welfare Ghana 2007). These institutions primarily offer a social environment in which care and protection are provided for vulnerable children through the hiring and training of workers referred to as caregivers. By employing people and paying them to deliver care services however, $\mathrm{CHs}$ also become work organizations and the $\mathrm{CH}$ environment becomes an occupational environment for the people employed to deliver the care services (Islam and Fulcher 2016). Occupational health issues therefore come into play in the $\mathrm{CH}$ environment. Individuals employed in this occupational context work in a variety of roles including 'core caregivers' (employees who are in day-to-day contact with the children in residence working as hired 'parents'), social workers, health workers, teachers, institutional directors and volunteers (Darkwah et al. 2016).

The nature of the care services required of employees in this context is complex (Darkwah et al. 2016; World Health Organization 2004). As noted by Islam and Fulcher (2016), there is no intervention that is more immediately consequential than those provided by residential child care workers. Their responsibilities range from providing physical protection and care to responding holistically to emotional, psychological and all other needs of the children (Bettmann et al. 2015; Groark et al. 2005; WHO 2004; Zeanah et al. 2005). Further, CWPC in care institutions often come from troubled backgrounds, the reason for which it is deemed necessary to admit them into the institutions in the first place (Frimpong-Manso 2016; Rizzini and Rizzini 2009:165; United Nations Children's Fund 2003; United Nations General Assembly 2010). There can be little doubt that providing adequate care for these children poses a considerable challenge to employed caregivers and the institutions they work for. The delivery of the care service in this sector therefore requires complex planning, organization and funding. Particularly, it becomes clear that the organizational structure ${ }^{2}$ (the strategies or styles in which care is organized and delivered to the children) and funding sources

\footnotetext{
${ }^{1}$ In this paper CWPC refers to children in residential care

${ }^{2}$ We use 'organizational structure' to refer to how work activities are organized in the CHs. In other studies in the literature, the concept has much broader definitions and goes beyond just this.
} 
(the organizations or persons providing monetary and resources support) of these institutions would be two crucial factors in determining the successes of the institutions in carrying out their responsibilities (Hearle and Ruwanpura 2009a; Smyke et al. 2002). Most importantly, these two factors could also hold significant implications for the health - (physical, mental and social well-being (World Health Organization 1948)) as well as the work (specific activities or tasks that caregivers are expected to perform) of employed caregivers.

\section{Organizational Structure of CHs and Possible Implications for Employees}

Care institutions vary in their structuring (Abebe 2009). While some operate as conventional boarding facilities with dormitory-style accommodation and shiftworking caregivers, others operate as 'villages' with family-like environments where the children live as 'brothers' and 'sisters' with a 'mother' (employed core caregiver) in a family home permanently (Abebe 2009; Dozier 2012; SOS Kinderdorf International 2004). Globally, when governments have to utilize the 'last-resort' of residential institutions to organize care for CWPC, care strategies with family-like environments are preferred (Department of Social Welfare Ghana 2008; Whetten et al. 2009). This is due to observations that children grow best in family environments where care is continuous allowing children and caregivers to develop lasting bonds (FrimpongManso 2016; Yendork and Somhlaba 2015). However, such organizational structuring is expensive to operate and resource deficits coupled with rising numbers of CWPC have meant that both family-style and conventional dormitory-style institutions still operate in places like Africa (Abebe 2009; Mann et al. 2012). Such is the case in Ghana where both dormitory-style and family-style $\mathrm{CH}$ structures exist (Frimpong-Manso 2016).

Cross-disciplinary workplace research consistently demonstrates that how work is structured or organized in an organization has influences on work performance, health and work experiences of employees (Chen and Huang 2007; Griffin et al. 2007; Kanten et al. 2015; Wilson et al. 2004). In the specific context of care work, research indicates that the care recipient's needs (which often informs the work strategy or structure adopted) determines the demands made on the caregiver which in turn have implications for the health and well-being of the caregiver (Beach et al. 2005; Pinquart and Sorensen 2003; Talley and Crews 2007). Further, arguments put forward by the health promotion theory of Salutogenesis (Antonovsky 1993) hint at the possible influences of environments on individuals by arguing that the nature of an environment may present stressors and resources to individuals in that environment which in turn have implications for their functioning or health. The theory holds that whether individuals manage to remain healthy or function properly depends on: (1), the extent to which they experience that environment as understandable and that a sense of order can be sustained even in unknown circumstances (Comprehensibility), (2), the extent to which individuals believe that there are adequate resources to deal with prevailing stressors (Manageability) and (3), the extent to which individuals are convinced that things make sense and what people do in life is worth the energy they invest in it (meaningfulness). According to Antonovsky (1993), these make up the Sense of Coherence (SOC) and this SOC is significantly associated with health trajectories or outcomes. Thus, by their nature and characteristics, the varying organizational structures and care strategies 
adopted by $\mathrm{CHs}$ may present employed caregivers with varying opportunities or resources as well as stressors in their line of work that may have implications for the specific demands made on them and their physical, mental or social well-being. For example, while the 'mother' in a family-style $\mathrm{CH}$ is, by principle, committed to staying with the children in the home full time (including day and night every day (Cahajic et al. 2003)), the caregiver in the dormitory-style $\mathrm{CH}$ is limited in her interaction with the children by working hours (Abebe 2009).

Interestingly, research on the impact of the organization of care and the characteristics of the care environment in the CWPC institutional work space tends to emphasize the outcomes of these arrangements and organizational characteristics for the children. Attention is rarely paid to how these influence care workers (van IJzendoorn et al. 2011; Wolff et al. 1995; Wolff and Fesseha 1998). The resulting evidence therefore sheds much insight into better alternative care arrangement options for CPWC without offering much about the situation of workers in these arrangements and what could be done about it. Interventions have therefore been carried out more in the interest of the children than in the interest of employees.

\section{Funding Sources of CHs and Possible Implications for Caregivers}

Ownership and funding sources of work organizations are also known to have influences on various employee and organizational outcomes (Comondore et al. 2009; Lyons et al. 2006; Mihajlov and Mihajlov 2016). For example, while research in some contexts suggests that employees in government-owned organizations fare better than private-owned organizations (Mihajlov and Mihajlov 2016) others suggest the opposite in other contexts (Ntukidem and Ntukidem 2011). In a meta-analytic review of the literature, Comondore et al. (2009) found differences in nursing care quality between institutions owned and funded by for-profit organizations and those owned and funded by not-for-profit organizations. The investigators concluded that not-for-profit institutions provided higher quality care. In the child-care work sector, ownership, operational responsibility and funding sources of care institutions have been observed to differ. Institutions may be funded through sources such as government and Non-governmental Organizations (NGOs) as well as benevolent individuals and religious organizations (Abebe 2009; Ennew 2005). In Ghana, the government owns, operates and funds a few $\mathrm{CHs}$, with the larger proportion owned and funded by individuals and private, often not-for-profit organizations mostly operating without governmental oversight (Better care network 2014; DSW 2008; Frimpong-Manso 2016).

Funders typically have expectations of the institutions they support. The funding strategy and requirements from funders may, like its organizational form, pose significant influence to $\mathrm{CHs}$ and on the work demands made of caregivers. For instance, $\mathrm{CHs}$ in Ghana are, by law, required to raise CWPC in their care with compliance to children's rights provisions enshrined in the United Nations Conventions on the Rights of the Child (UNCRC) (Department of Social Welfare 2008). Funders, both local and foreign expect CHs benefitting from them to fully comply with this law. The use of UNCRC principles in raising children is however a contentious issue in local Ghanaian society. Cultural norms of child upbringing in this context emphasize practices such as corporal punishment and strict parental control - practices that clash with some of the provisions in the UNCRC (Kyei-Gyamfi 2011; Twum-Danso 2012). Funder insistence on the use 
of these laws therefore often generates tensions between child rights-centered programmes (especially foreign-funded ones) and local folk (see Darkwah et al. 2018) Thus similar to arguments raised by Daniel (2014) concerning how humanitarian aid may help or harm recipient communities, funders' expectations and requirements of care institutions for CWPC may exert influences that may help or stress those employed as caregivers. Further, Hearle and Ruwanpura (2009b) observe that government grant systems for orphan care institutions in South Africa posed severe challenges to caregivers by way of bureaucratic application procedures and corruption among government officers. Colburn (2010) also found that private orphanages in Ghana fared better in providing care for CWPC than public orphanages due to monitoring and resource differences. Yet such existing comparative investigations into $\mathrm{CHs}$ overwhelmingly emphasize the outcomes of such funding and resource differences for the health and wellbeing of the resident children and much less on what these mean for the health, wellbeing and working lives of caregivers as employees. The implication is that the work situation of employed caregivers on whose successes the health and wellbeing of the resident children significantly depend is largely understudied.

\section{Research Questions}

This study was conducted for the purpose of providing insight into the work situation of employed caregivers in CHs. The idea was to explore how employees experience working in the different $\mathrm{CH}$ organizational structures and the influences that funding sources and funder expectations have on their work and health. Two research questions were explored:

1. How does the organizational structure of a children's home influence the work and health of employee caregivers?

2. How do funding sources and funder expectations affect caregivers in children's homes in Ghana?

\section{Method}

\section{Setting}

The study was carried out in three regions of Ghana, West Africa. The regions have some of the country's largest government-owned and private-owned $\mathrm{CHs}$ which receive funding and resource support from different sources. The $\mathrm{CHs}$ present in these regions also have different organizational structures. Some operate with traditional dormitory-style structure (even though they like to see themselves as families) while others operate the typical family unit structure. These settings were therefore purposefully sampled in order to collect data from across the different organizational structures and funding sources.

\section{Design}

We adopted a qualitative approach with phenomenological design for this exploration. We chose this method and design because of our interest in obtaining in-depth insight 
into caregivers' subjective as well as shared lived experiences and meaning making of the phenomenon of caregiving as a job within the different $\mathrm{CH}$ organizational and funding structures. Researching occupational health issues in this work setting is still a new and emerging area so the qualitative approach gave us a better opportunity to explore with an inductive approach to capture emerging insights. Since a qualitative approach is best suited for in-depth analysis of the whys and hows of individual lived experiences and how people construct reality for themselves in different contexts (Cho and Trent 2006; Swift and Tischler 2010), using the method and design was appropriate for answering our research questions.

\section{Participants}

Fifty-seven caregivers drawn from three CHs participated in the study. The caregivers held different positions and responsibilities in their organizations and therefore played different roles in the provision of care services. We included caregivers with the different responsibilities in order to better capture information from a broader spectrum of experiences regarding the phenomenon of CWPC caregiving. There were 41 core caregivers ('mothers', 'fathers' and 'aunties' in charge of raising the children in the dormitories or family homes), three social workers, two resident health workers, five teachers, three institutional directors, and three volunteers who were former institutional children) involved in the study.

\section{Data Procedures}

The lead author collected data using a combination of participant observation, focus group discussions and in-depth interviews. The techniques were employed in a systematic way such that information from one built on information from others. He began with participant observations where he stayed with or paid frequent visits to each participating institution for at most one month, observing caregivers as they went about their daily routines and taking the opportunity to develop rapport with caregivers. He kept a field notebook in which he jotted down observations. He also used the participant observation phase to recruit focus group discussion and interview participants through friendly informal conversations in which the study and its purpose were explained to interested caregivers.

Focus group discussions followed shortly after participant observation in each institution. Three focus group discussions were held in total with an average of eight participants (all of them 'mothers' and 'aunties') per discussion. The group discussions were used to collect information on lived experiences and shared norms regarding the phenomenon of CWPC caregiving and how the particular $\mathrm{CH}$ organizational structure and funding source influences this activity. The lead author played a facilitator role in each of the group discussions. Themes put forward for discussion were: "what are the work responsibilities of a caregiver in this institution?", "how does the organizational form/style of this institution affect your work as a caregiver", "who are the main funders of this institution?" and how do the funding source and funder expectations influence your work as a caregiver?". The discussions took place on the institutional compounds and took an average of two hours and ten minutes to complete. 
In-depth, face-to-face interviews completed the data collection. The interviews were used to try and collect additional information, gain more depth into already provided experiences and provide a private space for caregivers who might have been possibly uncomfortable to share their experiences in public. In all, 53 interviews were conducted including 19 interview participants who had already participated in focus group discussions. Each interview took place at a time and place chosen by the participant and in either Twi (local Ghanaian Language) or English depending on the preference of the participant. The interviews were conducted using a thematic interview guide with the same themes as those used for the focus groups. The interviews lasted for an average of one hour and $35 \mathrm{~min}$.

The order of progression (observation - focus groups - interviews) was done purposefully to first pick up initial data from general open observation which would then serve as bases for more specific thematic discussions in the focus groups. Combined information from the observations and focus groups then served as bases for further, deeper probes during interviews. Overall, the combination of the three qualitative data techniques ensured multiplicity of data sources for the study and also culminated in a tripod of data sources upon which triangulation was achieved.

\section{Ethics}

We obtained ethical clearance for the study from the Norwegian Social Sciences Data Services (NSD). The Department of Social Welfare (DSW) of the Government of Ghana reviewed this institutional clearance and deemed it satisfactory for the study to be conducted before data collection began. We then obtained permissions from the authorities of the individual institutions involved. We fully informed participants about the nature and purpose of the study and also informed them about their right to refuse participation or withdraw participation at any point without any sanctions. We made it clear that participation was voluntary and would come at no compensation. Those who agreed signed informed consent forms before being involved in the study. The focus group discussions and interviews were audio-recorded with the full consent of the participants. All collected data were stored in a password-protected folder on the personal computer of the lead author. Co-authors and co-coders had access only to anonymized forms of this data.

\section{Data Analysis}

We began our analysis process by first transcribing and translating all audio-recorded data. The transcripts together with field notes from participant observation were then coded by individual members of a coding team. The team agreed to adopt an inductive coding process where members studied the transcripts carefully and picked out units of information that specifically described the situation being recounted in the transcripts as codes. To ensure inter-coder reliability, each individual member separately coded the data before the team met to discuss the codes and find consensuses on coding disagreements to obtain a final coding frame. This inductive coding process was followed by a deductive thematic network analysis following Attride-Sterling's approach (Attride-Stirling 2001). We adopted this approach in order to be able to identify 
emerging themes in the text and better understand the complexity of participant experiences by uncovering the underlying meanings and interconnections between the various emerging themes. We began with clustering codes that expressed similar meanings into basic units or Basic Themes. Basic themes expressing similar meanings were then further clustered into Organizing Themes and the same procedure was used to cluster organizing themes into a larger umbrella theme called Global Theme. The Global Theme captures the essence of the entire data-set collected. Table 1 presents the systematic thematic analysis process we adopted:

Table 1 Thematic Network Analysis of the data-set

\begin{tabular}{|c|c|c|c|}
\hline Codes & Basic themes & Organizing & Global \\
\hline & & themes & themes \\
\hline $\begin{array}{l}\text {...dormitory style means too many children per caregiver } \\
\text {...being in charge of a house means taking care of } 40 \text { children } \\
\text {...It's difficult with this style, you get overwhelmed with work } \\
\text {...your role shifts from being a caregiver to so many other things }\end{array}$ & $\begin{array}{l}\text { Dormitory-style } \\
\text { increases work } \\
\text { demands on } \\
\text { caregiver }\end{array}$ & \multirow{4}{*}{$\begin{array}{l}\text { Impacts of } \\
\text { organization } \\
\text { al structure } \\
\quad \text { on } \\
\text { caregiving } \\
\text { work }\end{array}$} & \multirow{13}{*}{$\begin{array}{l}\text { Impacts of } \\
\text { organizational } \\
\text { structure \& } \\
\text { funding } \\
\text { sources on } \\
\text { caregiver } \\
\text { work and } \\
\text { health }\end{array}$} \\
\hline $\begin{array}{l}\text {...this style of care doesn't make us parents } \\
\text {...the children don't have a bond with you, they only see a worker } \\
\text {...this style makes it look like a boarding school instead of home } \\
\text {...we close from our parenting duties, so it's difficult to bond }\end{array}$ & $\begin{array}{l}\text { Dormitory-style } \\
\text { makes bonding } \\
\text { difficult }\end{array}$ & & \\
\hline $\begin{array}{l}\text {... with our family style, there are no starting and closing times for us } \\
\text {... with this family style there are no working days and weekends for us } \\
\text {...the pay does not match the hours we work } \\
\text {...the difficulty with this style is that you are on the job } 24 / 7\end{array}$ & $\begin{array}{l}\text { Family-style is } \\
\text { physically } \\
\text { demanding }\end{array}$ & & \\
\hline $\begin{array}{l}\text {...the children easily bond with each other with this family style } \\
\text {...the caregiver is seen as a parent figure in the family home } \\
\text {...The children get a sense of family } \\
\text {...the number of children is smaller with this style }\end{array}$ & $\begin{array}{l}\text { Family style } \\
\text { makes work } \\
\text { outcomes better } \\
\text { for the children }\end{array}$ & & \\
\hline $\begin{array}{l}\text {...Slips and falls are common with dorm style because of work pressure } \\
\text {...At the end of your shift, you go home with body ache all over } \\
\text {...despite everything, you close and go home to rest } \\
\text {...that sense of relief when you finally close feels so good }\end{array}$ & $\begin{array}{l}\text { Dormitory-style } \\
\text { influences } \\
\text { physical health }\end{array}$ & \multirow{4}{*}{$\begin{array}{l}\text { Impacts of } \\
\text { organization } \\
\text { al structure } \\
\text { on caregiver } \\
\text { health }\end{array}$} & \\
\hline $\begin{array}{l}\text {...one mother with } 10 \text { kids in family home, you develop blood pressure } \\
\text {...we work non-stop with family style, you get exhausted everyday } \\
\text {...with this family style, you have no rest }\end{array}$ & $\begin{array}{l}\text { Family style } \\
\text { influences } \\
\text { physical health }\end{array}$ & & \\
\hline $\begin{array}{l}\text {...we don't get to be with our own families often } \\
\text {...you lose all your friends because your life is in the CH family home } \\
\text {...you can't attend family social gatherings, you become a stranger }\end{array}$ & $\begin{array}{l}\text { Family-style } \\
\text { affects social } \\
\text { well-being }\end{array}$ & & \\
\hline $\begin{array}{l}\text {... with this style, if your child is not doing well in school, you bear the guilt } \\
\ldots \text { to understand and respond to } 10 \text { different kids drains you mentally } \\
\ldots \text { the separation from your own biological family is mentally challenging }\end{array}$ & $\begin{array}{l}\text { Family-style } \\
\text { affects caregiver } \\
\text { mental health }\end{array}$ & & \\
\hline $\begin{array}{l}\text {...foreign funders expect foreign parenting with child rights } \\
\text {...sometimes what they expect you to do is confusing } \\
\text {...They pay, so they expect you to obey without complain } \\
\text {...foreign funding comes with confusing child rights }\end{array}$ & $\begin{array}{l}\text { Foreign funding } \\
\text { comes with } \\
\text { confusing work } \\
\text { demands }\end{array}$ & \multirow{2}{*}{$\begin{array}{l}\text { Impacts of } \\
\text { funding } \\
\text { sources on } \\
\text { caregiving } \\
\text { work }\end{array}$} & \\
\hline $\begin{array}{l}\text {...we are funded mainly by government, so we don't have much } \\
\text {...the government never brings the money on time } \\
\text {...if local sources fund you, you can parent like a Ghanaian } \\
\text {...you don't get much training with local funding }\end{array}$ & $\begin{array}{l}\text { Government/ } \\
\text { local funding } \\
\text { affects work } \\
\text { performance }\end{array}$ & & \\
\hline $\begin{array}{l}\text {...foreign funding enables } \mathrm{CHs} \text { to support caregiver health costs } \\
\text {...foreign funders provide much more work resources easing work stress } \\
\text {... with foreign funding we train a lot which helps us do the work in healthy } \\
\text { ways }\end{array}$ & $\begin{array}{l}\text { Foreign funding } \\
\text { supports } \\
\text { caregiver health }\end{array}$ & \multirow{3}{*}{$\begin{array}{l}\text { Impacts of } \\
\text { funding } \\
\text { sources on } \\
\text { caregiver } \\
\text { health }\end{array}$} & \\
\hline $\begin{array}{l}\text {...foreigners fund you, so you parent like them and your own conscience } \\
\text { judges you } \\
\text {...the local community sees you as only spoiling the children not parenting } \\
\text { them } \\
\text {...foreign funders brings foreign rules which conflict with our parenting } \\
\text { values and make us feel guilty }\end{array}$ & $\begin{array}{l}\text { Foreign funding } \\
\text { affects caregiver } \\
\text { mental \& social } \\
\text { well-being }\end{array}$ & & \\
\hline $\begin{array}{l}\text {...we bear our own health care costs because we are funded locally } \\
\text {...local funding means less resources, which means more work stress } \\
\text {...We don't train much so we don't know much about healthy work } \\
\text { practices }\end{array}$ & $\begin{array}{l}\text { Local funding } \\
\text { influences } \\
\text { caregiver health } \\
\text { on the job }\end{array}$ & & \\
\hline
\end{tabular}




\section{Results}

Themes that emerged from our systematic analysis process describe the experiences and accounts of employees regarding what the organizational structure of their institutions and the sources of funding and resources mean for their work and health. They also capture how expectations and conditions from funders influence their work as caregivers. We present these results here under the main organizing themes that emerged:

\section{Impacts of Organizational Structure on Caregiving Work}

Caregiver accounts and field observations revealed various ways (positive and negative) in which the organizational structure of $\mathrm{CHs}$ influence the phenomenon of care and what this means for those employed to provide it in that sector. In some cases, the different structures had similar implications for the demands made on caregivers although through different pathways. For example, the dormitory-style of organizing care implied that the workload for caregivers was high as few caregivers were placed in charge of large numbers of children in large accommodations increasing the work stress level on the caregivers:

“...because of the style we operate, we have too many children under sometimes just two caregivers...that brings overwhelming stress to them as employees. The work demands become just too much for the caregivers" (Resident nurse, dormitory style $\mathrm{CH}$ )

An assistant house mother shared this experience:

"...there are too many children under one house mother and sometimes just one assistant on duty because this place is more like a dormitory...there was a time I had to feed 40 children all by myself...it's too stressful..."(Assistant house mother, dormitory-style $\mathrm{CH}$ )

Similarly, caregivers in the family-style $\mathrm{CH}$ structure also felt their work was too demanding and stressful not because of high child-caregiver ratio but because they are required to live permanently with the children in the family homes and never 'close from work':

“... with our style, we don't have a time to go to work and a time to close... we live here permanently with the children and we work practically every day, every minute...the demands are just too much sometimes...(Mother, family-style $\mathrm{CH}$ )"

In other cases, there were differences in the influences that the organizational structure had on the caregiving work. This mainly had to do with caregiver relations with the children which caregivers felt was crucial for effective work performance. Caregivers in the dormitory-style $\mathrm{CH}$ for instance, felt that their organizational structure made bonding with the children difficult because of the near impossibility 
to pay individual attention to each child and also because of the shift work system that comes with that design. This perception was common during focus group discussions:

"...because of the way the care service here is organized, we struggle to build bonds with the children so they (the children) treat us just as we are - workers not parents...you can't really care for them like you would do for your own child, and yet, that is what we are employed to do..." (House mother, dormitory-style unit)

During an interview, another caregiver said:

"...I would say this style of caregiving is not the best for the children because of the shifts we run...there is no continuity in the parenting they receive so it is difficult for the children to bond as siblings and then to bond with caregivers...this affects our work a lot..."(House mother, dormitorystyle $\mathrm{CH}$ )

Caregivers in the family-style organizational structure rather felt that the structure influences their work by facilitating bonding between the children and between the children and caregivers. They thought this was positive as it made work performance relatively easier:

"...I think this family unit form of organizing care is better for the children compared to those other styles like the dormitory styles... here the children live together in smaller family units with a mother... so they see themselves as siblings and handling them is easier for us..." (Mother, family-style $\mathrm{CH}$ )

A social worker in a family-style organizational structure shared a similar opinion:

"...From the way we organize the care service here, it's not possible to cram many children into one family home... so the children actually do have a sense of family and belonging...the caregivers have relatively smaller numbers of children..." (Social worker, family-style $\mathrm{CH}$ )

Caregivers in the dormitory-style CHs agreed with the thoughts of those in the familystyle $\mathrm{CH}$ workers on this:

“...The way we are organized here makes the job more stressful for us... and does not provide the children with optimum care... it is not like those family-style CHs where they look like real families...that is better for the children..." (Assistant house mother, dormitory-style $\mathrm{CH}$ ).

Thus while the structures of the CHs presented high levels of work stress to caregivers (albeit through different pathways), the family-style organization had some positive influences on caregiver work performance and children's growth while the dormitorystyle organization largely impacted negatively on these. 


\section{Impacts of Organizational Structure on Caregiver Health}

Some of the impacts that the structures of the CHs have on caregiver work performance also tended to hold implications for their health and safety on the job. Here again, similarities and differences emerged in the nature of the health impacts. For example negative influences on physical health of caregivers were shared across the two organizational structures attributed largely to the work demands and high stress levels. While a caregiver in a dormitory-style $\mathrm{CH}$ said:

“...slips and falls are a part of the job in this place...especially in the mornings on weekdays when we have to get all of them ready for school... it can get crazy I tell you..."(Assistant house mother, dormitory-style $\mathrm{CH}$ )

another in a family-style $\mathrm{CH}$ said:

“...well, I if you work permanently $24 / 7$ without break or without a sense of closing time, obviously that's not good for your health, is it?... exhaustion can kill...(Auntie, family-style $\mathrm{CH}$ )

Also there were complaints of high blood pressure which caregivers attributed to the work demands brought on by the nature of organization across both organizational structures:

"...I am aware that some of my colleagues have become ill with hypertension and other things after they joined this job here...I mean, from the way the whole care is arranged, why wouldn't they get hypertension after working in this set-up for a long time..." (Mother, dormitory style $\mathrm{CH}$ )

From the family-style organization, a caregiver said:

“... Since I joined this home, I have developed high blood pressure...I am often alone with 10 children... I have to cook, wash and clean... what kills me is the talking... sometimes you practically have to scream before they listen to you.... and if anything goes wrong, the office blames you the mother..." (Mother, family-style $\mathrm{CH}$ )

Aside from the shared concerns for physical health of caregivers across organizations, the family-style organization in particular seemed to have additional negative influences on caregiver mental health:

“...This organizational form is good, but only for the children...for us, it means you hardly see your own family...you are left longing for them and wondering what's happening with them...that drains you mentally...it's hard to deal with" (Mother, family-style $\mathrm{CH}$ )

Another caregiver shared this experience:

“...my teenage daughter is now pregnant and we don't even know who made her pregnant...because I left her in somebody's care while I came here to care for 
other people's children. I can't stop blaming myself...the guilt is heavy...sometimes I just lock myself up and cry...(Mother, Family-style $\mathrm{CH}$ )

Some caregivers in the dormitory-style CHs seemed aware of the inherent mental health implications of the family-style $\mathrm{CHs}$ and preferred to work where they are:

"...I would rather work here than in those family unit organizational styles. At least here, we close and go home to see our own children...you look forward to closing time to get away from all this.... in those family style homes, there is no escape...longing for your family can mess up your mind... (Mother, dormitorystyle $\mathrm{CH})$.

There were also social costs of the family-style organization for the caregiver:

“...you become a stranger to your community...they don't see you at community gatherings...you don't attend funerals...your excuse is work...if something happens to you, people will say they are also going to work... who will help you?..."(Mother, family-style $\mathrm{CH}$ )

Other staff including institutional gatekeepers and educational workers agreed to the health implications of the family-style for caregivers:

“... I guess when this style was adopted, the authorities were probably thinking of what's best for the children, not so much the employee...the children are vulnerable and need complex care, so they probably forgot to think about what this would mean for the health of people who sign up as caregivers..." (Educational worker, family-style $\mathrm{CH}$.)

An institutional director said:

“...I don't think our policy caters well for the people we have employed as caregivers...everything is about the children...I admit the children should be our first priority...but we can't achieve our goals if we don't take good care of the people in whose care we entrust them..."(Director, family-style $\mathrm{CH}$ ).

\section{Impacts of Funding Sources on Caregiving Work}

The ownership and sources of funds and other resources to run the CHs also had a variety of influences on how caregivers performed their work roles in the organizations. Again, there were similarities and differences in these impacts with the differences observed mainly in the extent of the impacts. For example caregivers in both privately funded and locally funded $\mathrm{CHs}$ expressed frustrations regarding the rules that they are expected to follow in carrying out their parenting work. Participant caregivers felt frustrated with the requirement to use the UNCRC as they thought the rules are foreign and conflict with their own local values of parenting. Interestingly, the severity of the frustration seemed higher on the part of 
the caregivers in locally funded $\mathrm{CHs}$ while the degree of enforcement of these provisions seemed higher in the privately funded CHs:

“...Sometimes you are just confused...all these rules from foreigners...how do they expect me to raise a child like how white people raise their children...you can't discipline them... you just watch them get spoiled...it's just frustrating..." (Mother, government-funded $\mathrm{CH}$ )

A caregiver from a privately-funded $\mathrm{CH}$ however said:

"...well, they train us here to obey the rules of child rights... over time we have learnt to accept them and just work with them...you convince yourself that it is not your fault that the children are getting spoilt..." (Mother, private funded $\mathrm{CH}$ )

Stark differences were observed in how child rights regulations were enforced in the government versus private funded CHs. In informal conversations during participant observations, caregivers revealed these differences:

Caregiver from government funded $\mathrm{CH}$ :

"...here, we are funded by the government and the government knows the local norms, so yes they make sure that we adhere to child rights, but sometimes they understand if we have to go the local way..."(Mother, government-funded $\mathrm{CH}$ )

Caregiver from privately-funded $\mathrm{CH}$ :

“...you can lose your job or even face prosecution if you breach those child rights rules here...the money for this place comes from white people and some rich people who have lived abroad so they are very strict with those rules...you just leave the children alone if you don't want trouble..." (Auntie, privatefunded $\mathrm{CH}$ ).

Funding sources also influenced caregiver work performance by influencing the frequency of training caregivers received. Caregivers unanimously agreed that training was important in helping them understand their roles and handle the stress in the work better. In this sense caregivers felt that those working in private-funded homes perform better on the job than those in governmentfunded ones:

“...you see, we here are funded by foreign, western donors, so they run this place almost like how other homes in Europe and America are run...training is frequent and that helps us deal with the stressors in this job..." (Mother, Private $\mathrm{CH}$ )

A government -funded $\mathrm{CH}$ caregiver said:

"...I can say that in my 15 years of service in this institution I have attended training only twice...the government never has money ...so obviously those rich private home workers do better on the job than us..." (Mother, government $\mathrm{CH}$ ) 
The funding sources again influenced caregiver work performance by determining the quantity and availability of material resources available to caregivers for the performance of their work roles. Again the odds were in favour of privately-funded homes:

“...I can't remember a time when school has re-opened and even one child here lacks anything to go to school...they are superb with releasing materials and money for the children... you have to commend them for that..." (Aunty, Private-funded $\mathrm{CH}$ )

A volunteer in the government $\mathrm{CH}$ said:

"... On several occasions some mothers here have had to use their own small salaries to purchase items needed for the children's upkeep because the government money does not come on time..." (Volunteer, government funded $\mathrm{CH}$ )

Institutional heads in the private organizations expressed awareness of the influence that funding sources were having on the caregivers' ability to perform the tasks required of them:

“...here, we give them everything they need...so they keep the children neat, feed them and all...it is not like the locally-funded homes where the children look dirty because their caregivers don't have the needed materials..." (Director, private-funded $\mathrm{CH}$ )

\section{Impacts of Funding Sources on Caregiver Health}

Like the organizational structures, the funding sources also had implications for the health and wellbeing of the caregivers at work. One key area where funding influence on caregiver health was observed concerned issues of institutional support systems for employee health care costs. Privately funded $\mathrm{CH}$ workers testified that their institutions support their health care costs because they receive funding from abroad:

“...As for our health issues, we receive some help from our employers with, for example, health bills...we get money from abroad so they pay like $50 \%$ of the total cost for us and we also pay the other $50 \%$..." (mother, private-owned $\mathrm{CH}$ )

Government $\mathrm{CH}$ workers rather lamented about the total lack of support for their health costs:

"...We go through all this stress and when we fall ill, who is there to support us?...we have to use that small salary they pay us to pay our hospital bills... it makes you feel so unappreciated..."( mother, government $\mathrm{CH}$ ).

A social worker in one of the institutions summarized the influences of funding on employee health issues in an informal conversation during participant observation: 
“...it's simple, how your health matters are handled as an employee in an organization like this depends very much on who owns the organization and how it obtains funds to run the place... if your institution is funded by foreign donors, like Europeans or Americans, you can be sure they will pay for your health, but if it is owned by the government here, forget it, you are on your own..." (Social worker, private-owned $\mathrm{CH}$ ).

Other impacts that funding sources had on employee health were in a way, chain effects of impacts brought on by the funder influences on work responsibilities. Caregivers from across the organizations agreed that the funding sources influence the rules of the job (child rights) which in turn brings them a sense of guilt and confusion making the job mentally stressful:

“...you see, we are parents ourselves so we know how to raise children...so when they ask us to follow rules that only end up spoiling the children's behavior, we as parents, have a sense of guilt...that is not mentally healthy for us...(Mother private funded $\mathrm{CH}$ )

A caregiver from the government $\mathrm{CH}$ said:

"...there are times when I have arguments with myself in my head especially when the big children stand up to you and say things to you and you can't do anything because of child rights...you feel sad and depressed..."(Mother, government-funded $\mathrm{CH}$ ).

The funder expectations of caregivers to adhere strictly to child rights provisions, seems not only to bring mental challenges to caregivers, but also social costs:

“...the local community don't think anything good of us...they think we are adults who have sold our values for money and just spoil people's children..." (Mother, private funded $\mathrm{CH}$ )

During focus group discussion a caregiver shared this experience:

“...once I tried to advise a local woman to stop beating her child... she yelled at me and told me that if I know how to raise children I should teach the children in my care to show some respect to elders instead of just following white people and spoiling them..."(Mother, private-funded $\mathrm{CH}$ )

For the government-funded $\mathrm{CH}$, much of the chain effect impacts had to do with the funder's inability to provide adequate work resources, which in turn increases the stress levels in the job and through that influences their health:

“...Because we don't have much resources here, we are always stretched tight... if the home vehicle does not have fuel, we caregivers have to walk long distances to buy materials and carry them on our heads into this compound...in no time, 
you develop back pain and chronic body pain...it is not easy here...( assistant mother, government-funded $\mathrm{CH}$ )

In essence, our findings seem to reveal a peculiar impact pattern where organizational forms present certain work demands which then present certain physical and psychosocial health risk factors to caregivers with the nature and level of demands as well as the severity of risk factors influenced by funding sources. Figure 1 gives diagrammatic presentation of this pattern. It must be noted that this figure represents what was found in this particular study and might need further testing in subsequent research:

\section{Discussion}

In this study we explored the impacts of organizational structures (traditional dormitory style vs family unit style) and funding sources (government funding vs private funding) of children's homes in Ghana on the work and health of employed caregivers.

We found that both organizational structures, as they were practiced in the $\mathrm{CHs}$ involved in this study, increased the amount of workload on caregivers, which they felt limited their ability to carry out their work duties of providing adequate care. In the dormitory-style $\mathrm{CHs}$ this was attributed to high child-caregiver ratio, while in the familystyle $\mathrm{CHs}$ it was attributed to the requirement for the mother to live full time with the children and be constantly working to provide care without break or 'closing from work'. This finding holds important implications. First, it confirms earlier perceptions that dormitory-style institutional arrangement for CWPC is not beneficial for the caregivers' work and the growth of the children in residence (Delap 2011). However it also reveals that the general perception that the family-style of organizing care is better than the traditional dormitory style (see Delap 2011; DSW 2008; Frimpong-Manso 2016; Whetten et al. 2009; Yendork and Somhlaba 2015) may only be true for the children but not so much for the employees. Dormitory style $\mathrm{CHs}$ had additional negative influences on caregivers' work through the shift work systems; caregivers found this disrupted continuity of care and hindered their ability to build their role as 'parents' to the children. Existing research into child care confirms these caregiver perceptions as it demonstrates that the changing of core-caregivers through such means as shift-work schedules disturbs continuity and stability in the care relationship between caregivers and children and orchestrates behavioural problems in children (Browne 2009; Han 2008).

We found that the organizational structures of $\mathrm{CHs}$ affect the physical, mental and social health of caregivers at work. Physically, the heavy workload in both structures

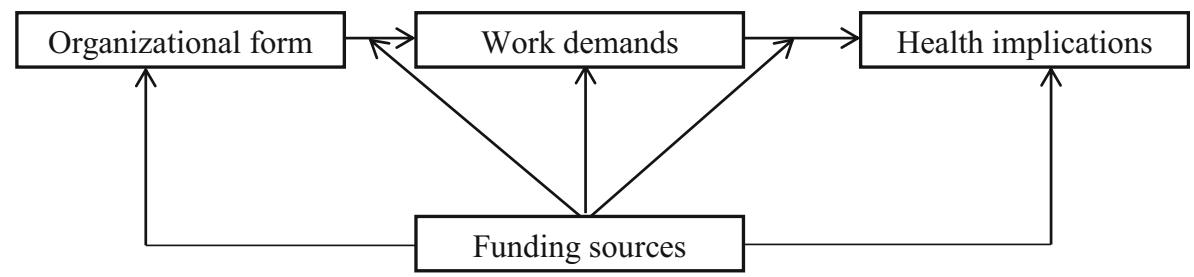

Fig. 1 Impact pattern between organizational forms, funding sources, work demands and health implications for caregivers in $\mathrm{CHs}$ 
contributed to caregiver feelings of exhaustion and overwhelming work stress. Existing literature demonstrates that such employee perceptions whether actual or imagined have an impact on satisfaction, commitment and productivity (Patterson et al. 2004; Raziqa and Maulabakhsha 2015). Concerning caregiver mental health, we found the dormitory style organizational structure to be better than the family-style arrangement. The full time commitment required of mothers in the family-style structure significantly limited the amount of time they were able to spend with their own families. Caregivers in the dormitory style arrangement perceived that having an end to the work day is positive for their mental health as it offers them an "escape" opportunity from their often stressful work environment and a chance to spend time with their own families. There is overwhelming research evidence that an employee's negative mental state affects their work behaviour (Chen et al. 2017; Rajgopal 2010; Sahler and Dubois 2009). Given the fact that caregiver work behaviours have frequently been called into question in the Ghanaian residential child care contexts (Anas 2010, 2015; FrimpongManso 2016; Smith-Asante 2014) the need for debate and reconsideration of the current states of the organizational structures could not be more urgent. Caregiver absence from the lives of their own families and local communities also seemed to come with social costs for the caregivers in the family-style CHs. Our findings show that caregivers felt alienated from their communities and feared losing their social networks and receiving social support as a result of the requirements of their organizational sturtures. Analyzing the family-style structure in its present state inside the Ghanaian social context, the caregivers fears hold merit as Ghanaian traditional social relations are organized by the principle of reciprocity reflected in traditional sayings such as "one shows benevolence to the child of his benefactor" (Fenenga et al. 2015; Ferrara 2003:1; Yidana 2014). The prospect of losing social capital or social support as a result of their organization's strategy is a cause for concern as previous research shows social capital and social support are crucial for individual social and mental health (Berkman and Glass 2000). Going by our findings, we argue that modifications need to be considered to make the care system more supportive of employee health.

The impacts of the funding sources on caregiver work performance varied in nature and severity. We found that funding sources were connected to the nature and frequency of on-the-job training that caregivers received. The $\mathrm{CHs}$ funded by private, often western sources, tended to undergo frequent training which, helped increase caregivers skill in handling their work roles better. $\mathrm{CHs}$ funded by local government had less frequent training. The implication here is that caregivers in the private homes had the knowledge to interpret their work roles better, and stood a better chance of adopting more effective ways of handling the work demands as compared to those in government-funded CHs. Consequently, work outcomes are likely to be better in the privately funded homes (and this has been observed in earlier research, see Colburn 2010) while perceived stress and inability to provide adequate care would be more likely in the government-funded homes. Funding sources also influenced the extent to which stipulated laws and regulations, in particular, child rights that residential child-care institutions in Ghana are required to follow in carrying out their duties are enforced. There have been challenges in enforcing this law in general Ghanaian society (see Darkwah et al. 2018; KyeiGyamfi 2011) but our findings reveal that in the $\mathrm{CH}$ context the extent of enforcement is related to who is paying. The strict application of UNCRC 
principles in raising children in the privately-funded $\mathrm{CHs}$ seemed to however be a point of conflict between institutional authorities who were more concerned about meeting funder expectations, and core-caregivers who were more concerned about meeting local community expectations of raising children the 'Ghanaian way'. The implication is that the privately-funded $\mathrm{CH}$ work environment likely has more tension due to the disagreements between institutional authorities and corecaregivers on this matter. These tensions, as observed in earlier workplace research (Castro and Martins 2010; Carter et al. 2013) may hold negative implications for work performance in the $\mathrm{CH}$. While this finding suggests a need for more attention to be paid to education and training of both institutional authorities and caregivers on more positive and cooperative ways of discussing and utilizing children's rights principles for the benefit of their work, it also exposes a possible weakness in the enforcement strategies adopted by the local Ghana government regarding the UNCRC. Beyond the Ghanaian context, this finding highlights the complexities in universal applications of international laws and principles in different social and cultural contexts (Welbourne and Dixon 2015) and the need for continuous debate aimed at developing more effective ways of encouraging acceptance of such laws in local contexts.

Generally, the influences that funding source has on caregiver health manifests through its influences on their work performance, with the exception of influence on support for caregiver health care costs. In essence, the health implications of the funding sources for caregivers in this regard were more negative for governmentfunded $\mathrm{CH}$ workers than private, western funded $\mathrm{CH}$ workers. The simple implication here is that funding strategies for government $\mathrm{CHs}$ need to be reviewed with more budgetary considerations given to $\mathrm{CHs}$ as this finding, together with findings of earlier research, demonstrate how inadequate funding undermines caregivers' work in government CHs in Africa (Ntukidem and Ntukidem 2011; Hearle and Ruwanpura 2009b). We found funding sources to also influence social and mental well-being of caregivers through their role in adherence to children's rights principles. The local communities' negative perceptions regarding using these principles to raise children means that the foreign funders' insistence on using children's rights principles, put the private $\mathrm{CH}$ workers in particular on a sort of a 'collision course' with the local communities where they work. Our findings demonstrate this as caregivers recounted experiencing hostile attitudes from local community folk due to their approach to raising the children in their care. Thus while caregivers faced friction on the issue of child rights with their superior officers on the one hand, they faced hostile reactions from the local community on the other on the same issue. The implication is that the social environment of caregivers within and outside the walls of their institutions is quite unsupportive. This kind of social situation in itself is a potential mental health risk factor for individuals in any context (Kawachi and Berkman 2001; Rutter 2005). We suggest that stakeholder consideration of interventions aimed at addressing these human relations issues in the $\mathrm{CH}$ should also target wider community education to increase understanding of children's rights principles. This would help change local community attitudes towards children's rights principles and caregivers eventually.

Funding sources also had quite a significant influence on employee health issues by being a key determinant of the amount of financial support caregivers received for their own health care costs. Our findings show that caregivers in the private, western funded 
CHs received some support with their health care costs while local government funded $\mathrm{CH}$ workers received no such support. Thus even though caregivers in the private funded CHs still complained about the institution's lack of urgency in providing this financial support compared to when such support is required for the children, this finding still implies that caregivers in the private $\mathrm{CHs}$ had better conditions of service and could approach their work duties more confidently. With no guarantee that their institutions would support them financially should any health consequence arise while performing their work duties, research suggests that employees' motivation, work engagement and commitment would likely be negatively affected (Arshadi 2011; Setti and Argentero 2011; Gillispie 2012). The eventual implied outcome in this situation is that private CHs are likely to perform better in providing care for CWPC than government CHs.

The observed impact of organizational structure and funding source on the work performance and health of caregivers in $\mathrm{CHs}$, also has implications for the growth and welfare of the children (Gray et al. 2017). Our findings show the care quality children in the $\mathrm{CHs}$ receive is likely to differ with children in the private-funded $\mathrm{CHs}$ standing a better chance of receiving good quality care. High child-caregiver ratio and increased work load imply that caregivers are even less able to carry out the duties expected of them (Bass et al. 2016). Caregiver training can significantly improve the situation and dramatically improve bonding and relationships between children and caregivers (Hermenau et al. 2015; Hermenau et al. 2017). Thus while we confirm that the small group family-style organizational form is a better option for the children, we also recommend that more has to be done in order for it to better support caregiver work performance and health.

\section{Limitations}

This study was qualitative in approach and design as our aim was to generate information regarding lived experiences and meaning making of people who work as caregivers in children's homes in the Ghanaian context. This means that our methods primarily concentrated on obtaining subjective views and experiences of care workers in this unique work context. Our findings therefore best apply to the context of study as cross-context generalization may not be best practice. However our findings do provide grounds for similar studies to be conducted in contexts similar to Ghana where such institutions are in use. The limited numbers of participants and geographical scope of this study also means that within Ghana, further studies may be needed to obtain a complete picture of the entire CWPC caregiving work scene. The use of techniques such as participant observation also means that the lead author stayed with participants and interacted with them on regular basis to make observations. Reflexively, author biases in interpreting findings and possible influences on participant willingness and candidness in giving information can therefore not be completely ruled out. It should however be noted that we took conscious steps to limit author subjectivity and bias in the data and this final report. The lead author (who collected the data) maintained awareness of possibility of bias (as recommended in qualitative research) and ensured he only played the role of facilitator during focus groups and conducted interviews in an open, non-threatening environment where participants were free to share experiences. Our use of a coding team to ensure inter-coder validity during data analyses also helped limit subjectivity. 


\section{Conclusion and Recommendations}

This study was conducted to investigate how the organizational structures and funding sources of children's homes in Ghana influence the work and health of employee caregivers. We had two research questions. First, we wanted to know how the organizational structure of a children's home influences work performance and health of employee caregivers and second, to find out how funding sources and funder expectations affect caregivers. We found that the influences that these two factors have for employed caregivers varied and followed a peculiar pattern: organizational structures present certain work demands (eg. high workloads, long duration on the job) which in turn present certain physical and psychosocial risk factors (eg. work stress \& exhaustion, separation from family) the severity of which is connected to funding sources. Funding sources impacted the level or severity of work demands and health risk factors as it was connected to the availability of materials and logistics needed for the job, frequency of caregiver training, support for caregiver health care costs, and the extent of adherence to children's rights regulations (which tended to affect caregiver relations with local community folk). In the light of our findings, we argue that there may be the need for stakeholder discussion and review of the current strategies adopted for organizing care for CWPC in residential institutions in Ghana and beyond as our findings reveal the possible limitations that are placed on caregiver ability to perform the duties expected of them with these current structures. The caregiver's position, health and wellbeing should be a focal point in such interventions as the health and wellbeing of the vulnerable children in this context significantly depends on the caregivers' health and wellbeing.

\section{Compliance with Ethical Standards}

Conflict of Interest On behalf of all authors, the corresponding author states that there is no conflict of interest.

Open Access This article is distributed under the terms of the Creative Commons Attribution 4.0 International License (http://creativecommons.org/licenses/by/4.0/), which permits unrestricted use, distribution, and reproduction in any medium, provided you give appropriate credit to the original author(s) and the source, provide a link to the Creative Commons license, and indicate if changes were made.

\section{References}

Abebe, T. (2009). Orphanhood, poverty and the care dilema: Review of global policy trends. Social Work and Society, 7(1), 70-81.

Anas, A. A. (2010). Orphan's home of hell. Retrieved from https://www.youtube.com/watch?v=KP__ gjW4vc.

Anas, A. A. (2015). 'CARE'less - The devil and the orphanage. Retrieved from https://www.youtube. com/watch?v=6-vEmlFhhsc.

Antonovsky, A. (1993). The structure and properties of the sense of coherence scale. Social Science and Medicine, 36(6), 725-733.

Arshadi, N. (2011). The relationships of perceived organizational support (POS) with organizational commitment, in-role performance, and turnover intention: Mediating role of felt obligation. Procedia - Social and Behavioral Sciences, 30(2011), 1103-1108.

Attride-Stirling, J. (2001). Thematic networks: An analytic tool for qualitative research. Qualitative Research, $1(3), 385-405$. 
Bass, J. K., Nakasujja, N., Familiar-Lopez, I., Alla, S. S., Murray, M., Opoka, R., . . Boivin, M. J. (2016). Association of caregiver quality of care with neurocognitive outcomes in HIV-affected children aged 2-5 years in Uganda. AIDS Care, 28(Supl. 1), 76-83. https://doi.org/10.1080/09540121.2016.1146215.

Beach, S. R., Schulz, R., Williamson, G. M., Miller, L. S., Weiner, M. F., \& Lance, C. E. (2005). Risk factors for potentially harmful informal caregiver behavior. Journal of American Geriatrics Society, 53, 255-261.

Berkman, L., \& Glass, T. (2000). Social integration, social networks, social support, and health. In L. Berkman \& I. Kawachi (Eds.), Social epidemiology (pp. 137-173). New York: Oxford University Press.

Better Care Network. (2014). Collected viewpoints on international volunteering in residential care centres, Country focus: Ghana. Retrieved from http://www.bettercarenetwork.org/bcn-in-action/bettervolunteering-better-care/activities-and-documents/collected-viewpoints-on-international-volunteering-inresidential-care-centres-country-focus-ghana

Bettmann, J. E., Mortensen, J. M., \& Akuoko, K. O. (2015). Orphanage caregivers' perceptions of children's emotional needs. Children and Youth Services Review, 49, 71-79.

Browne, K. (2009). The risk of harm to young children in institutional care. Fairfield: Save the Children.

Cahajic, S., Cvijetic, V., Darmati, I., Dupanovich, A., Haziosmaovich, M., \& Vukovic, S. S. (2003). Children and institutions in Bosnia and Herzegovina: First report of capacity building research. Sarajevo, Bosnia and Herzegovina:: UNICEF.

Carter, M. Z., Armenakis, A. A., Feild, H. S., \& Mos, K. W. (2013). Transformational leadership, relationship quality, and employee performance during continuous incremental organizational change. Journal of Organizational Behaviour, 34(7), 942-958.

Castro, M. L., Martins, N. (2010) The relationship between organisational climate and employee satisfaction in a South African information and technology organisation. S. A. Journal of Industrial Psychology/SA Tydskrif vir Bedryfsielkunde, 36(1), Art. \#800, 809 pages. https://doi.org/10.4102/sajip.v36i1.800.

Chen, C., \& Huang, J. (2007). How organizational climate and structure affect knowledge management-The social interaction perspective. International Journal of Information Management, 27(2007), 104-118.

Chen, Y., Li, S., Xia, Q., \& He, C. (2017). The relationship between job demands and employees' counterproductive work behaviors: The mediating effect of psychological detachment and job anxiety. Frontiers in Psychology, 8(1890). https://doi.org/10.3389/fpsyg.2017.01890.

Cho, J., \& Trent, A. (2006). Validity in qualitative research revisited. Qualitative Research, 2006(6), 319-340.

Colburn, J. (2010). Orphanages of Accra: A comparative case study on orphan care and social work practices. Retrieved from http://digitalcollections.sit.edu/cgi/viewcontent.cgi?article=1843\&context=isp_collection.

Comondore, V. R., Devereaux, P. J., Zhou, Q., Stone, S. B., Busse, J. W., Ravindran, N. C., . . Guyatt, G. H. (2009). Quality of care in for-profit and not-for-profit nursing homes: Systematic review and metaanalysis. BMJ, 339:b2732. https://doi.org/10.1136/bmj.b2732.

Daniel, M. (2014). Iatrogenic violence? Lived experiences of recipients of aid that targets vulnerable children in makete. Tanzania. Forum for Development Studies, 41(3), 415-431.

Darkwah, E., Daniel, M., \& Asumeng, A. (2016). Caregiver perceptions of children in their care and motivations for the care work in children's homes in Ghana: Children of god or children of whitemen? Children and Youth Services Review, 66(C), 161-169.

Darkwah, E., Daniel, M., \& Yendork, J. S. (2018). Care-'less': Exploring the interface between child care and parental control in the context of child rights for workers in children's homes in Ghana. $B M C$ International Health and Human Rights, 2018(1), 13. https://doi.org/10.1186/s12914-018-0151-9.

Delap, E. (2011). Scaling down: Reducing, reshaping and improving residential care around the world. London: EveryChild.

Department of Social Welfare (DSW) Ghana. (2007). Standards for operation of residential care settings in Ghana. Accra: Government of Ghana.

Department of Social Welfare (DSW) Ghana. (2008). Regulations for care and protection of children without appropriate parental care in Ghana. Accra: Ministry of Manpower, Youth and Employment.

Dozier, M. (2012). Institutional care for young children: Review of literature and policy implications. Social Issues Policy Review, 6(1), 1-25. https://doi.org/10.1111/j.1751-2409.2011.01033.x.

Engle, P., Groza, V., Groark, C. J., Greenberg, A., Bunkers, K. M., \& Muhamedrahimov, R. (2011). The situation for children without parental care and strategies for policy change. In R. B. McCall, M. H. van IJzendoorn, F. Juffer, C. J. Groark, \& V. K. Groza (Eds.), Monographs of the Society for Research in Child Development (Vol. 76, pp. 190-222).

Ennew, J. (2005). Prisoners of childhood: Orphans and economic dependency. In J. Qvortrup (Ed.), Studies of modern childhood: Society, agency and culture (pp. 128-146). London: Palgrave.

EveryChild. (2009). Missing: Children without parental care in international development policy. London: EveryChild. 
Fenenga, C. J., Nketiah-Amponsah, E., Ogink, A., Arhinful, D. K., Poortinga, W., \& Hutter, I. (2015). Social capital and active membership in the Ghana National Health Insurance Scheme - a mixed method study. International Journal for Equity in Health, 2015(14), 118.

Ferrara, E. L. (2003). Kinship groups and reciprocity: A model of credit transactions in Ghana. The American Economic Review, 93(5), 1730-1751.

Frimpong-Manso, K. (2016). Residential care for children in Ghana: Strengths and challenges. In T. Islam \& L. Fulcher (Eds.), Global perspectives: Residential child and youth care in a developing world. Cape Town: The CYC-Net Press.

Gillispie, S. (2012). The effects of health benefit use on organizational and union commitment among full and part-time retail employees. All Thesis, paper 1380.

Gray, C. L., Ariely, S., Pence, B. W., \& Whetten, K. (2017). Why institutions matter: Empirical data from five low- and middle-income countries indicate the critical role of institutions for orphans. In A. V. Rus, S. R. Parris, \& E. Stativa (Eds.), Child maltreatment in residential care: History, research, and current practice. Cham: Springer International Publishing.

Griffin, M. A., Neal, A., \& Parker, S. K. (2007). A new model of work role performance: Positive behavior in uncertain and interdependent contexts. Academy of Management Journal, 50(2), 327-347.

Groark, C. J., Muhamedrahimov, R. J., Palmov, O. I., Nikiforova, N. V., \& McCall, R. B. (2005). Improvements in early care in Russian orphanages and their relationship to observed behaviors. Infant Mental Health Journal, 26, 96-109.

Han, W. (2008). Shift work and child behavioral outcomes. Work, Employment and Society, 22(1), 67-87.

Hearle, C., \& Ruwanpura, K. N. (2009a). Contentious care: Foster care grants and the caregiver-orphan relationship in KwaZulu-Natal Province. South Africa. Oxford Development Studies, 37(4), 423-437.

Hearle, C., \& Ruwanpura, K. N. (2009b). Contentious care: Foster Care grants and theCaregiver-orphan relationship inKwaZulu-Natal province. South Africa. Oxford Development Studies, 37(4), 423-437.

Hermenau, K., Goessmann, K., Rygaard, N. P., Landolt, M. A., \& Hecker, T. (2017). Fostering child development by improving care quality: A systematic review of the effectiveness of structural interventions and caregiver trainings in institutional care. Trauma, Violence, \& Abuse, 18(5), 544-561.

Hermenau, K., Kaltenbach, E., Mkinga, G., \& Hecker, T. (2015). Improving care quality and preventing maltreatment in institutional care - A feasibility study with caregivers. Frontiers in Psychology, 6(937). https://doi.org/10.3389/fpsyg.2015.00937.

Islam, T., \& Fulcher, L. (Eds.). (2016). Residential child and youth care in a developing world: Global perspectives. Cape Town: The CYC-Net Press.

Kanten, P., Kanten, S., \& Gurlek, M. (2015). The effects of organizational structures and learning organization on job embeddedness and individual adaptive performance. Procedia Economics and Finance, 23(2015), 1358-1366.

Kawachi, I., \& Berkman, L. (2001). Social ties and mental health. Journal of Urban Health. Journal of Urban Health, 78(3), 458-467.

Kyei-Gyamfi, S. (2011). Corporal punishment in Ghana. In R. K. Ame, D. L. Agbenyiga, \& N. A. Apt (Eds.), Children's rights in Ghana: Reality or rhetoric. Plymoyth: Lexington Books.

Lyons, S. T., Duxbury, L. E., \& Higgins, C. A. (2006). A comparison of the values and commitment of private sector, public sector, and parapublic sector employees. Public Administration Review, 66(4), 605-618.

Mann, G., Long, S., Delap, E., \& Connell, L. (2012). Children living with and Affcetd by HIV in residential care: Desk-based research. United Kingdom: Chloe Hall/EveryChild.

Mihajlov, S., \& Mihajlov, N. (2016). Comparing public and private employees' job satisfaction and turnover intention. MEST Journal, 4(1), 75-86.

Ntukidem, P. J., \& Ntukidem, E. P. (2011). Resource availability and distribution in public and private special education schools in Cross River state, Nigeria. International Education Studies, 4(3), 119-123.

O’Kane, C., Moedlagl, C., Verweijen-Slamnescu, R., Winkler, E. (2006). Child rights situation analysis: rights-based situational analysis of children without parental care and at risk of losing their parental care. Retrieved from http://www.soschildrensvillages.org.uk/files/reports-and-research/20070404_0820_ CRSA_final_Nov06_en.pdf.

Patterson, M., Warr, P., \& West, M. (2004). Organizational climate and company productivity: The role of employee affect and employee level. Journal of Occupational and Organizational Psychology, 77, 193-216.

Pinquart, M., \& Sorensen, S. (2003). Differences between caregivers and noncaregivers in psychological health and physical health: A meta-analysis. Psychology and Aging, 18(2), 250-267.

Rajgopal, T. (2010). Mental well-being at the workplace. Indian Journal of Occupational and Environmental Medicine, 14(3), 63-65.

Raziqa, A., \& Maulabakhsha, R. (2015). Impact of working environment on job satisfaction. Procedia Economics and Finance, 23(2015), 717-725. 
Rizzini, I., \& Rizzini, I. (2009). Children and youth in institutional care in Brazil: Historical perspectives and current overview. In M. E. Courtney \& D. Iwaniec (Eds.), Residential care of children: Comparative perspectives. New York: Oxford University Press.

Rutter, M. (2005). How the environment affectsmental health (editorial). British Journal of Psychiatry, 2005(186), 4-6.

Sahler, B., \& Dubois, A. (2009). A guide to the business case for mental health. Essen: BKK Bundesverband / ENWHP Secretariat.

Setti, I., \& Argentero, P. (2011). Organizational features of workplace and job engagement among Swiss healthcare workers. Nursing and Health Sciences, 2011(13), 425-432.

Smith-Asante, E. (2014). Children's homes reeling from inadequate funding. Daily Graphic. Retrieved from https://www.graphic.com.gh/news/general-news/children-s-homes-reeling-from-inadequate-funding.html.

Smyke, A. T., Dumitrescu, A., \& Zeanah, C. H. (2002). Disturbances of attachment in young children. I: The continuum of caretaking casualty. Journal of the American Academy of Child and Adolescent Psychiatry, $41,972-982$.

SOS Kinderdorf International. (2004). Manual for the SOS Children's Village organisation. In: SOS Kinderdorf International.

Swift, J. A., \& Tischler, V. (2010). Qualitative research in nutrition and dietetics: Getting started. Journal of Human Nutrition and Dietetics, 23, 559-566.

Talley, R. C., \& Crews, J. E. (2007). Framing the public health of caregiving. American Journal of Public Health, 97(2), 224-228.

Twum-Danso, A. (2012). "this is how we do it here": The persistence of the physical punishment of children in Ghana in the face of globalization ideals. In A. T.-D. Imoh \& R. K. Ame (Eds.), Childhoods at the intersection of the local and the global. United Kingdom: Palgrave Macmillan.

United Nations Children's Fund (UNICEF). (2003). Africa's orphaned generations. New York: UNICEF.

United Nations General Assembly. (2010). Guidelines for the alternative care of children : resolution / adopted by the General Assembly. Retrieved 18th January, 2015 http://www.unicef.org/spanish/videoaudio/PDFs/100407UNGA-Res-64-142.en.pdf

van IJzendoorn, M. H., Palacios, J., Sonuga-Barke, E. J. S., Gunnar, M. R., Vorria, P., McCall, R. B., . . Juffer, F. (2011). Children in institutional care: Delayed development and resilience. Monographs of the Society for Research in Child Development, 76(4), 8-30. https://doi.org/10.1111/j.1540-5834.2011.00626.x.

Welbourne, P., \& Dixon, J. (2015). Child protection and welfare: Cultures, policies. and practices. European Journal of Social Work, 19(6), 827-840.

Whetten, K., Ostermann, J., Whetten, R. A., Pence, B. W., O’Donnell, K., Messer, L. C., \& Thielman, N. M. (2009). A comparison of the wellbeing of orphans and abandoned children ages 6-12 in institutional and community-based care settings in 5 less wealthy nations. PLoS One, 4(12), e8169. https://doi.org/10.1371 journal.pone.0008169.

Wilson, M. G., DeJoy, D. M., Vandenberg, R. J., Richardson, H. A., \& McGrath, A. L. (2004). Work characteristics and employee health and well-being: Test of a model of healthy work organization. Journal of Occupational and Organizational Psychology, 2004(77), 565-588.

Wolff, P. H., Dawit, Y., \& Zere, B. (1995). The Solomuna orphanage: A historical survey. Social Science and Medicine, 40(8), 1133-1139.

Wolff, P. H., \& Fesseha, G. (1998). The orphans of Eritrea: Are orphanages part of the problem or part of the solution? American Journal of Psychiatry, 155(10), 1319-1324.

World Health Organization (WHO). (1948). Preamble to the constitution of WHO as adopted by the international health conference, New York, 19 June - 22 July 1946 and entered into force on 7 April 1948. New York: WHO.

World Health Organization (WHO). (2004). The importance of caregiver-child interactions for the survival and healthy development of young children: A review. Retrieved from http://www.google.no/url?sa= $\mathrm{t} \& \mathrm{rct}=\mathrm{j} \& \mathrm{q}=\& \mathrm{esrc}=\mathrm{s} \&$ source $=\mathrm{web} \& \mathrm{~cd}=1 \& \mathrm{ved}=0 \mathrm{ahUKEwj} 698 \mathrm{i}$ 8qHWAhXFORoKHVeTCA4 QFggmMAA\&url=http\%3A\%2F\%2Fwhqlibdoc.who.int\%2Fpublications\%2F2004\%2F924159134X. pdf\&usg=AFQjCNHjkgxygDnKdm3Qa2FrwTLSCm6Aww.

Yendork, J. S., \& Somhlaba, N. Z. (2015). Do social support, self-efficacy and resilience influence the experience of stress in Ghanaian orphans? An exploratory study. Child Care in Practice, 21(2), 140-159.

Yidana, A. (2014). Commoditization of ritualized occasion among women in northern Ghana. American Journal of Sociological Research, 4(2), 25-33.

Zeanah, C. H., Smyke, A. T., Koga, S. F. M., Carlson, E., \& The BEIP Core Group. (2005). Attachment in institutionalized and non-institutionalized Romanian children. Child Development, 76, 1015-1028. 